\title{
MONITORING AND PREDICTION OF LAND USE LAND COVER CHANGES AND ITS IMPACT ON LAND SURFACE TEMPERATURE IN THE CENTRAL PART OF HISAR DISTRICT, HARYANA UNDER SEMI-ARID ZONE OF INDIA
}

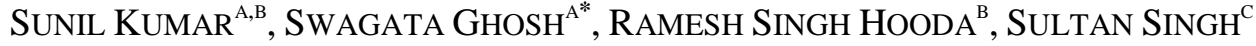 \\ ${ }^{a}$ Amity Institute of Geoinformatics and Remote Sensing (AIGIRS), Amity University, Sector \\ 125, Noida-201313, U.P., India \\ ${ }^{b}$ Haryana Space Applications Centre, CCS HAU Campus, Hisar,125004(Haryana)Hisar, \\ India \\ ${ }^{c}$ Haryana Space Applications Centre Node, Gurgaon New labour court building, Mini \\ Secretariat, Sector 11, Gurugram, Haryana 122001 \\ *Corresponding authore-mail: swagata.gis@gmail.com; sghosh1@amity.edu
}

Received: $24^{\text {th }}$ September 2019, Accepted: $7^{\text {th }}$ December 2019

\begin{abstract}
Land use Land cover have significance in relation to Land, the most vital and fundamental resource pertaining to the urban development. Unprecedented urban growth has a noteworthy impact on natural landscape by converting natural land-cover in Haryana. Hisar, an area recognized for rapid urban growth is less explored in terms of research. The present research has shown a significant change in land use in terms of expansion of built-up area from $3.7 \%$ (1991) to $5.0 \%$ (2001) and $6.2 \%$ (2011) by encroaching into agricultural land. Despite the clear difference between average land surface temperature for built up and non-built up area, grazing land and sandy waste, bare land in the rural surrounding possess higher temperature compared to the city core which contradicts the reported impact of urbanization earlier. Such contrary pertains to sparse vegetation cover leading to reduced evaporative cooling during dry pre-monsoon summer in the rural surrounding. On the other side, green parks and plantation in the city contribute to lower mean temperature because of high rates of evapotranspiration and produce 'oasis effect' in the present study area located in semi-arid climatic zone. Regression analysis between temperature and Normalized Difference Vegetation Index, Normalized Difference Built-up Index exhibited a strong negative and positive correlation respectively (Pearson's r: between -0.79 to -0.87 and between 0.79 to 0.84 respectively). Future land use prediction project an increase $(1.3 \%)$ in built-up area from 2011 to 2021 . This study recommends urban plantation and prohibition to overgrazing to check the heat effect.
\end{abstract}

Keywords: Land Use Land Cover; Urban growth modelling; Land Surface Temperature; Oasis effect; Spectral Indices; Remote Sensing.

\section{INTRODUCTION}

Worldwide land use and land cover (LULC) change in vast area along with rapid urbanization and population growth, has become an issue of major concern particularly in 
Kumar S., Ghosh S., Hooda R.S., Singh S.: Monitoring and prediction of land use land cover changes and its impact on land surface temperature in the central part of Hisar district, Haryana under semi-arid zone of India

developing countries (Newbold \& Scott, 2013; Ramachandra et al., 2012). As indicated by the United Nations (UN) and Population Reference Bureau- PRB (2000), about 3.3 billion people from the population has been dwelling in city areas and by 2030, this is anticipated to stretch to almost 5 billion. By 2030, $81 \%$ of urban population of developing world will be seen in town and cities (UNFPA, 2008). In such a scenario, the urban population in India is growing at about $2.3 \%$ per annum (Ramachandra \& Kumar, 2008) with the developing countries whose average annual rate of change of urban population is projected $2.27 \%$ during 2007-2025 (UNFPA, 2008). Recently, the 2018 Revision of World Urbanization Prospects prepared by the Population Division of the UN Department of Economic and Social Affairs (UN DESA) has predicted an addition of another 2.5 billion people to urban areas by 2050 and this report also states that Asia and Africa will contribute $90 \%$ of this addition. Moreover, it has also been projected that India will take the load of added 416 million urban dwellers by 2050 (UN, 2018). According to 2011 census, urban proportion is $30 \%$ of total population in India. Even though, such urbanized areas become centres of innovation for the global economy and contributed to the wealth of their respective nation (De Sherbinin et al., 2007), it is worth mentioning that, the rapid rates of urbanization and unplanned expansion of cities have resulted in several negative consequences like the depletion of open spaces and forest cover, increase in atmospheric Carbon monoxide (CO) (Imam \& Banerjee, 2016), surface water pollution (Weng, 2001), development of slum, insufficient infrastructure, higher pollution levels, poor quality of life, congestion, pressure on key resources and many more (Riffat et al., 2016; Ramachandra et al., 2012).

Migration of people to urban areas in search for livelihood contributes to rise the urban population and expansion of urban areas which is one of the major reasons for land conversion especially forest cover (Imam \& Banerjee 2016) and agricultural land (Luck \& $\mathrm{Wu}, 2002)$. Despite the small area coverage relative to the earth's surface, such intensified land conversion affects the quality of life at all geographic scales (Herold et al, 2005) and degrades the environment prominently by altering the land surface temperature (LST) and thus making hotter urban areas compared to the rural surroundings. Such urban pockets with higher temperature impose diversified impact in the form heat-induced mortalities (Hondula et al., 2012), air pollution (Weng \& Yang, 2006), water consumption (Gober et al., 2009) etc. To combat such rapid LULC change, spatio-temporal pattern analysis of LULC change, impact of such change over the thermal environment as well as the prediction of future land use are necessary which will provide the basic information to urban planners and decision makers for making development plans with a sustainable approach.

In this context, satellite remote sensing can play an important role as the conventional surveying, mapping techniques are expensive, time and labour consuming and there is lesser availability of such data for most of the urban area specially in developing countries. The free availability of Landsat TM/OLI images with acceptable spatial resolution (30m), repetitive coverage and multispectral monitoring to the scientific community enrich the continuous monitoring of LULC dynamics for longer period and even make possible to predict future land use. Various studies have successfully used such images for LULC mapping and change monitoring using visual interpretation, automated and semi-automated mapping techniques along with post-classification change detection technique (Islam et al., 2018; Dou \& Chen, 2017). Besides the descriptive analysis of past and present LULC pattern, prediction of future land use has also been performed by modeling of urban growth and land use/land cover change (Rodriguez-Galiano \& Chica-Olmo, 2012; Tewolde \& Cabral, 2011) with successful integration of remote sensing and GIS. While optical remote sensing can provide useful information in terms of LULC transformation, thermal band has been effectively used to 
estimate LST (Duan et al., 2019; Wang et al., 2018) and exhibit the spatial variation of LST with respect to LULC (Almalki \& Al-Namazi, 2019; Kayet et al., 2016).

Compared to those districts (Faridabad, Palwal, Nuh, Gurgaon, Rewari, Mahendragarh, Charkhi Dadri, Bhiwani, Jhajjar, Rohtak, Sonipat, Panipat, Jind, Karnal) of Haryana declared as a part of National Capital Region (NCR), Hisar is less explored in terms of research. Limited studies available for Hisar at the district and city level (Rajesh, 2018; Kumar et al., 2016; Kaushik et al., 2015; Shashikant et al., 2015; Jain et al., 1991) reported that small-scale industries, educational facilities, transportation development are the main factors responsible for the rapid urban growth and expansion of Hisar city along the National Highway (NH) no.10 and Sirsa road. Such uncontrolled expansion of built-up region in the central part of Hisar Tehsil has resulted into the loss of scrub land and productive agricultural land. Located in semi-arid climatic conditions, Hisar is characterized by scanty, erratic rainfall and dearth of natural drainage. In such a situation, rapid urbanization and anthropogenic interference increase the temperature along with the evapo-transpiration which contributes to natural concentrations of salt and thereby cause high salinity in the ground water. Moreover, waterlogging is another problem in the period of occasional rainfall because of the increase of impervious surface area due to the expansion of urban dwelling which prohibits percolation of surface water into the ground. It also hampers the ground water recharge in this area and thereby became one of the reasons of depletion of water table in different parts of Hisar Tehsil.

Looking into the manifold impact of rapid LULC change in Hisar, the present study has attempted the spatio-temporal pattern analysis of LULC change using the multi-temporal satellite images and investigated the impact of such dynamics on the LST over time. It has also attempted the prediction of future land use in this region which will contribute to prepare necessary management measures for a sustainable development.

Present study has been started from the hypothesis that urban growth in the central part of the study area can contribute to modify the LULC pattern. Such modified LULC pattern can act as a major factor in increasing temperature over the city core compared to the rural surrounding. In urbanized area, release of human-induced heat from high-concrete buildings in the residential, commercial and industrial area is the major reason behind the higher LST.

\section{STUDY AREA}

The study area lies in the central part of Hisar district and consists of Hisar tehsil (Latitudinal Extent: 28 $8^{\circ} 3^{\prime} 45^{\prime \prime} \mathrm{N}-29^{\circ} 26^{\prime} 27^{\prime} ' \mathrm{~N}$ Longitudinal Extent: $75^{\circ} 31^{\prime} 57^{\prime}$ 'E $75^{\circ} 54^{\prime} 42^{\prime \prime}$ ) (Fig. 1). Physiographically, Hisar plain covers the major part of Hisar tehsil. Because of the absence of natural drainage, the plain appeared as fertile with the introduction of irrigation through the development of extensive canal network as the branches of the Western Yamuna Canal and the Bhakra Canal. Small sized sand dunes are found in the tehsil in irregular interval as the district is bounded by Desert of Rajasthan in the south-western part. Being land-locked and located in the semi-arid climatic condition, it is characterized by dry air, irregular rainfall (average annual rainfall around $450 \mathrm{~mm}$, mostly during July and August) and drastic disparity of temperature. With the onset of winter season (from mid-November to mid-March) maximum daytime temperature ranges from 1.5 to $4{ }^{\circ} \mathrm{C}$ because of the passing western disturbances whereas during the summer season (from mid-March to end of June), the range is from 40 to $46^{\circ} \mathrm{C}$ and hot westerly winds (looh) affect the region. The present study area is agriculture dominated and minimal area is under forest cover especially tropical desert thorn species mostly of xerophytes. According to the Census 2011, the total population of Hisar tehsil is 1,069,309. Out of the total population, 
Kumar S., Ghosh S., Hooda R.S., Singh S.: Monitoring and prediction of land use land cover changes and its impact on land surface temperature in the central part of Hisar district, Haryana under semi-arid zone of India

4,23,945 (39.6\%) lives in urban areas. Considering the decadal change in population, it has been observed that Hisar tehsil has highest decadal growth of $14.1 \%$. Compared to the other tehsils, Hisar tehsil has experienced highest decadal growth $(37.98 \%)$ in the urban area also. The area is dominated by large, medium and small-scale industrial units, even the house-hold industry. Transport and communication system are well developed in this region in the form of National Highways (NH10; NH 65) and the Broad-Gauge Railway Lines (Rewari Bhiwani-Hisar-Sirsa and Hisar Jakhalmandi).

Fig. 1: Overview of the study area (as viewed on False Colour Composite with band combination $R=$ Near-Infrared, $G=\operatorname{Red}, B=G r e e n$ ) with location of field points. Numbers (1-52) indicate code of field points mentioned in Table 1.

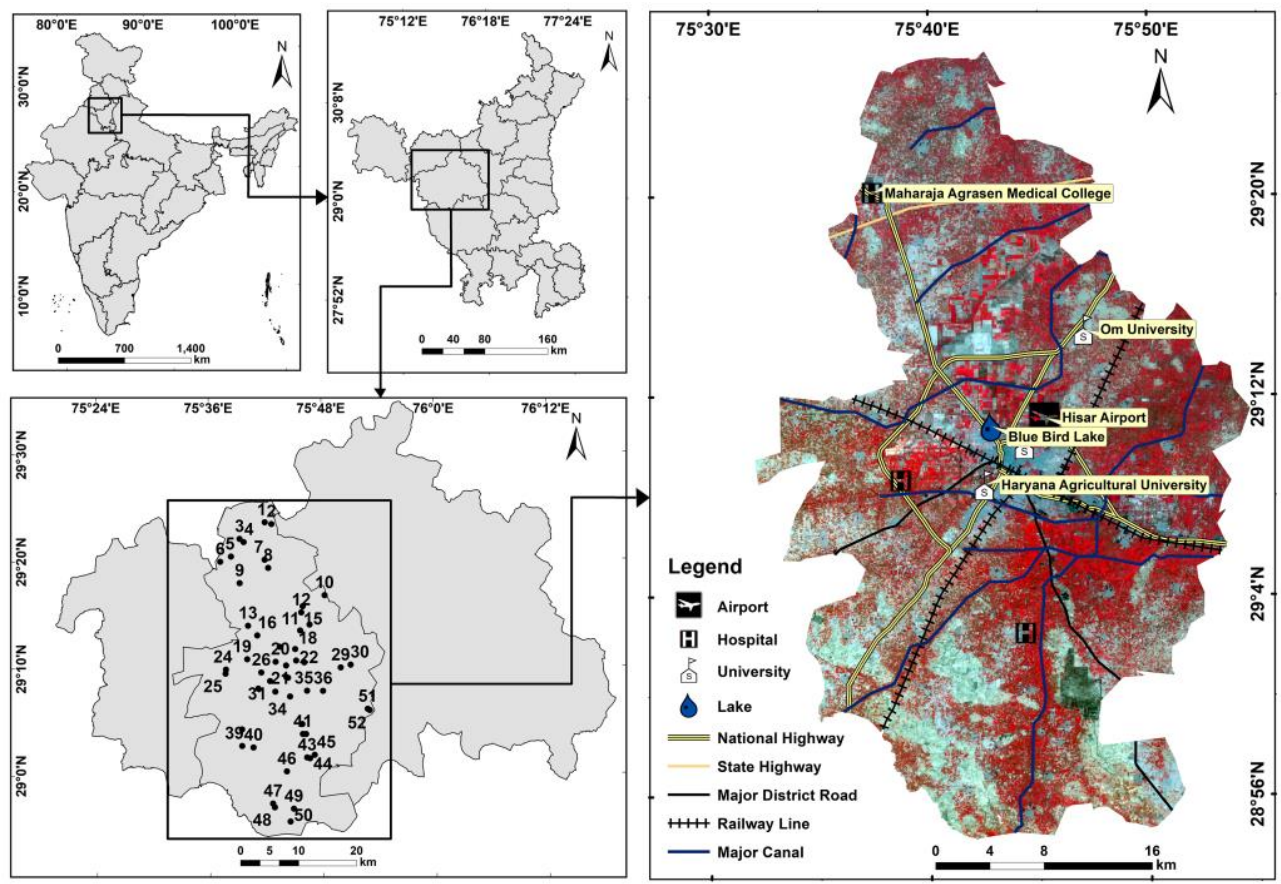

\section{DATA USED AND METHODOLOGY}

In this study, Landsat 5 Thematic Mapper (TM) image with optical bands (30 m spatial resolution) thermal band (120 m spatial resolution and resampled into $30 \mathrm{~m}$ ) acquired on 05 March 1991 (Image id: LT51470401991064ISP00; Path/Row-147/40), 16 March 2001 (Image id: LT51470402001075SGI00; Path/Row147/40) and 12 March 2011 (Image id: LT51470402011071KHC00; Path/Row147/40) downloaded from the United States Geological Survey (USGS) server have been used to prepare the LULC maps, LST maps and spectral indices of the study area. During the selection of satellite images to be used in the present research, all the cloud-free images acquired in the same months (March) and approximately at the similar local time with +/- 15 minutes (05 March 1991:10:15 AM, 16 March 2001:10:30 AM and 12 March 2011:10:45 AM) have been considered which makes the study more practicable. Furthermore, images acquired in March with less rainfall, more 
temperature are always preferable to identify LULC without ambiguity. All the data sets are terrain corrected with Universal Transverse Mercator (UTM) coordinate system, 43 North Zone and WGS 84 Datum. ASTER Global Digital Elevation Model (GDEM V2) has also been downloaded from the United States Geological Survey (USGS) server. The vector data of district and tehsil boundaries, streams, canals, railway lines and roads have been provided by the Haryana Space Applications Centre (HARSAC). Collection of field points has been carried out during the months of July 2016 for each LULC classes. At the selected field points, latitude and longitude, and LULC classes as attributes have been recorded using Garmin Map 62S hand-held Global Positioning System (GPS) (Fig. 2, Table 1).

Fig. 2: Field Photographs of different LULC in the study area. Numbers $(2,5,41$ and 43) indicate code of field points mentioned in Table 1.

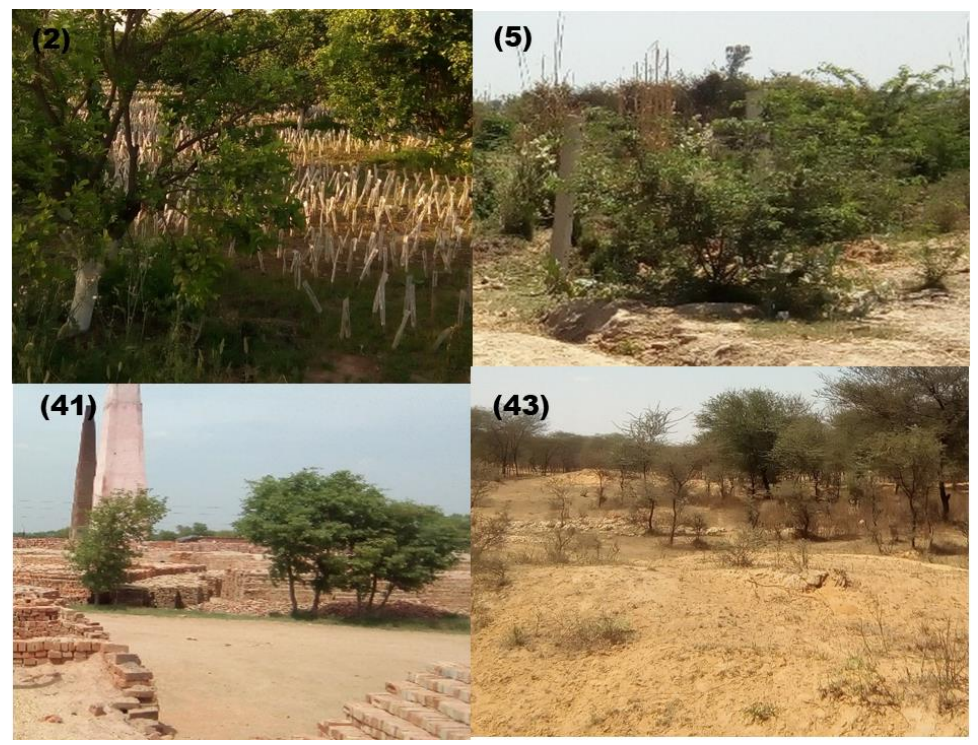

Table 1: Details of field Points collected at different sites in the study area

\begin{tabular}{|l|l|l|l|l|}
\hline $\begin{array}{l}\text { Field } \\
\text { Point } \\
\text { Code }\end{array}$ & $\begin{array}{l}\text { Latitude and } \\
\text { Longitude }\end{array}$ & Name of Place & Attribute & $\begin{array}{l}\text { Date of } \\
\text { collecting } \\
\text { Field Points }\end{array}$ \\
\hline 1 & $29.39^{\circ} \mathrm{N} 75.69^{\circ} \mathrm{E}$ & Kirmara Village & Waste land & $05-07-2016$ \\
\hline 2 & $29.39^{\circ} \mathrm{N} 75.71^{\circ} \mathrm{E}$ & Near kirmara Village & Horticulture & $05-07-2016$ \\
\hline 3 & $29.36^{\circ} \mathrm{N} 75.65^{\circ} \mathrm{E}$ & Near Kuleri Village & Horticulture & $05-07-2016$ \\
\hline 4 & $29.36^{\circ} \mathrm{N} 75.66^{\circ} \mathrm{E}$ & Govt School Kuleri & Built up & $05-07-2016$ \\
\hline 5 & $29.34^{\circ} \mathrm{N} 75.63^{\circ} \mathrm{E}$ & Mirpur Village & Grass/Grazing Land & $05-07-2016$ \\
\hline 6 & $29.33^{\circ} \mathrm{N} 75.61^{\circ} \mathrm{E}$ & Archaeology site Agroha & Waste Land & $05-07-2016$ \\
\hline 7 & $29.33^{\circ} \mathrm{N} 75.69^{\circ} \mathrm{E}$ & Nangthala Village & Agricultural Land & $05-07-2016$ \\
\hline 8 & $29.32^{\circ} \mathrm{N} 75.70^{\circ} \mathrm{E}$ & Nangthala Village & Water Body & $05-07-2016$ \\
\hline 9 & $29.29^{\circ} \mathrm{N} 75.65^{\circ} \mathrm{E}$ & Landhri Village & Waste Land & $05-07-2016$ \\
\hline 10 & $29.27^{\circ} \mathrm{N} 75.80^{\circ} \mathrm{E}$ & Bahbalpur Village & Water Body & $05-07-2016$ \\
\hline 11 & $29.26^{\circ} \mathrm{N}, 75.76^{\circ} \mathrm{E}$ & Juglan & Built up & $05-07-2016$ \\
\hline 12 & $29.25^{\circ} \mathrm{N}, 75.76^{\circ} \mathrm{E}$ & Juglan Village & Agricultural Land & $06-07-2016$ \\
\hline 13 & $29.23^{\circ} \mathrm{N}, 75.66^{\circ} \mathrm{E}$ & $\begin{array}{l}\text { National Seeds Corporation Near BSF } \\
\text { Camp Hisar }\end{array}$ & Built up & $06-07-2016$ \\
\hline
\end{tabular}


Kumar S., Ghosh S., Hooda R.S., Singh S.: Monitoring and prediction of land use land cover changes and its impact on land surface temperature in the central part of Hisar district, Haryana under semi-arid zone of India

\begin{tabular}{|c|c|c|c|c|}
\hline 14 & $29.23^{\circ} \mathrm{N}, 75.77^{\circ} \mathrm{E}$ & Splash park Marvel City & Water Body & 06-07-2016 \\
\hline 15 & $29.22^{\circ} \mathrm{N}, 75.76^{\circ} \mathrm{E}$ & Talwandi rana & Grass/Grazing Land & 06-07-2016 \\
\hline 16 & $29.21^{\circ} \mathrm{N}, 75.68^{\circ} \mathrm{E}$ & Near GLF Animal Dairy Farm & Built up & 06-07-2016 \\
\hline 17 & $29.19^{\circ} \mathrm{N}, 75.72^{\circ} \mathrm{E}$ & Back Side of Blue Bird Lake & Agricultural Land & 06-07-2016 \\
\hline 18 & $29.19^{\circ} \mathrm{N}, 75.75^{\circ} \mathrm{E}$ & Dear Park Hisar & Forest/reserved Area & 06-07-2016 \\
\hline 19 & $29.18^{\circ} \mathrm{N}, 75.66^{\circ} \mathrm{E}$ & Pirwali Village & Waste land & 06-07-2016 \\
\hline 20 & $29.17^{\circ} \mathrm{N}, 75.71^{\circ} \mathrm{E}$ & FCI Godown Anaz Mandi Hisar & Built up & 06-07-2016 \\
\hline 21 & $29.17^{\circ} \mathrm{N}, 75.73^{\circ} \mathrm{E}$ & Central Library G.J.U. Hisar & Built up & 06-07-2016 \\
\hline 22 & $29.17^{\circ} \mathrm{N}, 75.75^{\circ} \mathrm{E}$ & Near AirPort Hisar & Waste land & 06-07-2016 \\
\hline 23 & $29.17^{\circ} \mathrm{N}, 75.76^{\circ} \mathrm{E}$ & Near Hisar Airport & Agricultural Land & 06-07-2016 \\
\hline 24 & $29.16^{\circ} \mathrm{N}, 75.62^{\circ} \mathrm{E}$ & Hisar byepass Near Shahpur Village & Water Body & 06-07-2016 \\
\hline 25 & $29.15^{\circ} \mathrm{N}, 75.62^{\circ} \mathrm{E}$ & Hisar Bypass Naer Shahpur Village & Agricultural Land & 06-07-2016 \\
\hline 26 & $29.16^{\circ} \mathrm{N}, 75.69^{\circ} \mathrm{E}$ & CCS HAU & Agricultural Land & 06-07-2016 \\
\hline 27 & $29.15^{\circ} \mathrm{N}, 75.73^{\circ} \mathrm{E}$ & Mahabir Colony (water Works) & Water Body & 06-07-2016 \\
\hline 28 & $29.15^{\circ} \mathrm{N}, 75.73^{\circ} \mathrm{E}$ & Mahabir Colony near water Works & Agricultural Land & 06-07-2016 \\
\hline 29 & $29.16^{\circ} \mathrm{N}, 75.83^{\circ} \mathrm{E}$ & Niyana Village & Agricultural Land & 06-07-2016 \\
\hline 30 & $29.17^{\circ} \mathrm{N}, 75.84^{\circ} \mathrm{E}$ & Niyana village & Water Body & 06-07-2016 \\
\hline 31 & $29.14^{\circ} \mathrm{N}, 75.70^{\circ} \mathrm{E}$ & Nehru Library CCS HAU & Built up & 06-07-2016 \\
\hline 32 & $29.13^{\circ} \mathrm{N}, 75.68^{\circ} \mathrm{E}$ & Chandan Nagar near Balasmand Road & Agricultural Land & 06-07-2016 \\
\hline 33 & $29.13^{\circ} \mathrm{N}, 75.71^{\circ} \mathrm{E}$ & Sector 15 community Hall & Water Body & 06-07-2016 \\
\hline 34 & $29.12^{\circ} \mathrm{N}, 75.74^{\circ} \mathrm{E}$ & Secror16 & Waste Land & 06-07-2016 \\
\hline 35 & $29.13^{\circ} \mathrm{N}, 75.77^{\circ} \mathrm{E}$ & Industrial Jindal Steels & Built up & 06-07-2016 \\
\hline 36 & $29.13^{\circ} \mathrm{N}, 75.80^{\circ} \mathrm{E}$ & Near Hisar Bypass Hisar cantt & forest/ Reserved Area & 06-07-2016 \\
\hline 37 & $29.07^{\circ} \mathrm{N}, 75.65^{\circ} \mathrm{E}$ & Muklan & Grass/Grazing Land & $07-07-2016$ \\
\hline 38 & $29.07^{\circ} \mathrm{N}, 75.76^{\circ} \mathrm{E}$ & Mirkan Village & Water Body & $07-07-2016$ \\
\hline 39 & $29.04^{\circ} \mathrm{N}, 75.65^{\circ} \mathrm{E}$ & Kalwas & Grazing land & $07-07-2016$ \\
\hline 40 & $29.04^{\circ} \mathrm{N}, 75.67^{\circ} \mathrm{E}$ & Near Kalwas Singha Road & Agricultural Land & $07-07-2016$ \\
\hline 41 & $29.06^{\circ} \mathrm{N}, 75.76^{\circ} \mathrm{E}$ & Mangali Mohbat Village & Brick kiln & 07-07-2016 \\
\hline 42 & $29.06^{\circ} \mathrm{N}, 75.77^{\circ} \mathrm{E}$ & Mangali Mohbat Village & Waste land & $07-07-2016$ \\
\hline 43 & $29.02^{\circ} \mathrm{N}, 75.77^{\circ} \mathrm{E}$ & Bhojraj Village & Sandy Scrub & 07-07-2016 \\
\hline 44 & $29.02^{\circ} \mathrm{N}, 75.77^{\circ} \mathrm{E}$ & Bhojraj Village & Sand Minning & 07-07-2016 \\
\hline 45 & $29.03^{\circ} \mathrm{N}, 75.78^{\circ} \mathrm{E}$ & Bhojraj village & Water Body & $07-07-2016$ \\
\hline 46 & $29.00^{\circ} \mathrm{N}, 75.73^{\circ} \mathrm{E}$ & Daya Village & Grass/Grazing Land & 07-07-2016 \\
\hline 47 & $28.95^{\circ} \mathrm{N}, 75.71^{\circ} \mathrm{E}$ & Talwandi Rukka Village & Agricultural Land & 07-07-2016 \\
\hline 48 & $28.95^{\circ} \mathrm{N}, 75.71^{\circ} \mathrm{E}$ & Talwandi Rukka Village & Grass/Grazing Land & $07-07-2016$ \\
\hline 49 & $28.94^{\circ} \mathrm{N}, 75.74^{\circ} \mathrm{E}$ & Bure Village & Agricultural Land & 07-07-2016 \\
\hline 50 & $28.92^{\circ} \mathrm{N}, 75.74^{\circ} \mathrm{E}$ & Saharwa & Grass/Grazing Land & 07-07-2016 \\
\hline 51 & $29.10^{\circ} \mathrm{N}, 75.87^{\circ} \mathrm{E}$ & Mayar Toll Plaza & Builtup & $07-07-2016$ \\
\hline 52 & $29.10^{\circ} \mathrm{N}, 75.88^{\circ} \mathrm{E}$ & Near Delhi Public School & Agricultural land & 07-07-2016 \\
\hline
\end{tabular}

\section{LULC mapping}

An unsupervised classification technique with (Iterative Self-Organizing Data Analysis Technique Algorithm) ISODATA Clustering has been performed on all the three images using ERDAS Imagine 2014 to generate LULC maps for the three observation periods. Minor post-processing is required to remove the ambiguity between spectrally similar classes representing completely different LULC types to improve the accuracy of the classified maps. For this, reclassification technique has been used in GIS platform and correct classes are assigned to a land cover types which has been incorrectly classified. Such processing has been performed using field data (Table 1), high-resolution Google Earth images and land use land cover database prepared under "National Land Use/ Land Cover Mapping" project on 1:50,000 scale carried out by National Remote Sensing Centre (NRSC), Indian Space 
Research Organization (ISRO) (available in Bhuvan portal). Accuracy assessment of three classified maps for the year 1991, 2001 and 2011 has been performed by a method using an error matrix (Card, 1982; Congalton, 1991). The change in area of LULC between the observation periods has been calculated using post-classification comparison and has been discussed in section 4.1 .

\section{Estimation of LST using the Thermal band}

In the study, thermal infrared (TIR) band of Landsat 5 TM images of three dates (05 March 1991, 16 March 2001 and 12 March 2011) have been used to calculate the LST of the study area for the month of March.

Digital numbers (DNs) of the TM band6 have been first converted to Top of Atmospheric (TOA) radiance by the following Eq.1 proposed by Markham and Barker (1986).

$$
L_{\lambda}=\frac{L_{\text {max }}-L_{\text {min }}}{Q_{\text {cal max }}-Q_{\text {cal min }}} \times\left(Q_{c a l}-Q_{c a l \text { min }}\right)+L_{\text {min }} \lambda
$$

Where,

$L_{\lambda}=$ Spectral radiance at the sensor's aperture

$Q_{c a l}=$ Quantized calibrated pixel value $[\mathrm{DN}]$

$Q_{\text {cal } \min }=$ Minimum quantized calibrated pixel value

$Q_{\text {cal } \max }=$ Maximum quantized calibrated pixel value

$L_{\min }=$ Spectral at-sensor radiance that is scaled to $Q_{c a l \text { min }}$ (available from the header file)

$L_{\max }{ }_{\lambda}=$ Spectral at-sensor radiance that is scaled to $Q_{\text {cal max }}$ (available from the header file)

Spectral radiance at the sensor's aperture $\left(L_{\lambda}\right)$ has been converted to at-sensor brightness temperature considering uniform emissivity using the Eq.2:

$$
T_{B}=\frac{K_{2}}{\ln \left(\frac{K_{1}}{L_{\lambda}}+1\right)}
$$

Where,

$T_{B}=$ at-sensor brightness temperature in Kelvin

$L_{\lambda}=$ Spectral radiance at the sensor's aperture

$K_{1}=$ Calibration Constant (available from the header file)

$K_{2}=$ Calibration Constant (available from the header file) 
Kumar S., Ghosh S., Hooda R.S., Singh S.: Monitoring and prediction of land use land cover changes and its impact on land surface temperature in the central part of Hisar district, Haryana under semi-arid zone of India

Estimation of land surface emissivity (LSE) is essential for the accurate computation of LST. LSE corrected LST has been computed using the Eq.3 following Artis and Carnahan (1982):

$$
L S T=\frac{T_{B}}{1+\left(\frac{\lambda \times T_{B}}{\rho}\right) \ln \varepsilon}
$$

Where,

$\lambda=11.5 \mu \mathrm{m}$ for thermal band for Landsat 5 (the central wavelength of emitted radiance)

$\rho=\frac{h \times c}{\rho}=1.438 \times 10^{-2} m k$ (h denotes the Planck Constant equals $6.626 \times 10^{-34} j s ; \mathrm{c}$ denotes the velocity of light equals $2.998 \times 10^{8} \mathrm{~m} / \mathrm{s} ; \sigma$ denotes the Boltzmann constant equals $1.38 \times 10^{-23} \mathrm{~J} / \mathrm{K}$

$\mathcal{E}=\mathrm{LSE}$

LSE ( $\varepsilon$ ) has been estimated using the Eq.4 following Estoque et al. (2017):

$$
\varepsilon=m P_{v}+n
$$

Where,

$m$ (0.004) and $n$ (0.986) have been used (Sobrino et al., 2004)

$P_{v}=$ Vegetation Proportion

$P_{v}$ has been estimated using the Eq.5 (Carlson \& Ripley, 1997)

$P_{V}=\left(\frac{N D V I-N D V I_{\min }}{N D V I_{\max }-N D V I_{\min }}\right)^{2}$

LST in Kelvin has been finally converted to degree Celsius by LST (Kelvin)-273.15.

\section{Derivation of Spectral Indices}

Using the high reflectivity in NIR region and comparatively low reflectivity in the RED region, Normalized Difference Vegetation Index (NDVI) facilitates the estimation of surface vegetation cover. It is worth to mention that NDVI is subject to seasonal conditions (Zhang et al., 2009), which was one of the reasons behind selecting cloud-free images of the same month (March) for the present study. Moreover, in Hisar, it has been observed that this period is nearly hot and almost dry with least variation in relative humidity. However, NDVI is an important indicator of surface radiant temperature (Lo et al., 1997). Additionally, the thermal condition of any urban region is linked to the drop of evapotranspiration due to the loss of vegetation cover, therefore, it is beneficial to correlate NDVI and LST. NDVI has been computed by dividing the difference of reflectance between RED band $(0.63-0.69 \mu \mathrm{m})$ and NIR band $(0.76-0.90 \mu \mathrm{m})$, available in TM image by the sum of the two-reflectance using Eq. 6: 


$$
N D V I=\frac{N I R-R E D}{N I R+R E D}
$$

Likewise, Normalized Difference Built-up Index (NDBI) has been computed by dividing the difference of reflectance between NIR band $(0.76-0.90 \mu \mathrm{m})$ and MIR band (1.55-1.70 $\mu \mathrm{m})$, available in TM image by the sum of the two-reflectance using Eq. 7 following Zha et al. (2005):

$$
N D B I=\frac{M I R-N I R}{M I R+N I R}
$$

\section{Correlation analysis between LST and LULC, Spectral Indices}

To examine the probable relationship between spatial variation of LST with LULC, NDVI and NDBI, zonal statistics have been extracted considering the LULC map, LST map, NDVI map and NDBI map using ArcGIS. The entire study area has been divided into 126943 zone of $100 \mathrm{~m} \times 100 \mathrm{~m}$ size. Mean values of LST has been computed within each zone and associated with LULC class and mean NDVI and NDBI of that each zone. A regression analysis has been performed between mean LST and mean NDVI. Likewise, another regression analysis has also been carried out between mean LST and mean NDBI values. A detailed discussion regarding the relationship spatial variation of LST with LULC, NDVI and NDBI has been discussed in section 4.2.

\section{Prediction of Future Land Change Scenario}

To predict the future land use change scenario, Land Change Modeller (LCM) (Idrisi Terrset 18.08) has been used. LCM is based on Markov chain matrices and transition susceptibility maps has been successfully applied to categorize trends in LULC change of arid/semi-arid regions in earlier studies (Ansari \& Golabi, 2019; Gibson et al., 2018). Details of the methods and tools offered by the model has been discussed in Mas et al. (2014). For the present study, two LULC maps of two different dates having the same classes are analysed to evaluate gains and losses between landcover classes, deduce the patterns and process of change by calculating types of transition and rate of change with respect to some influencing factors in LCM model. Such analysis enables the user to assess the degree of vulnerability of that area towards change through transition potential modelling and thus predict spatial distribution of LULC in future (Kolb et al., 2013).

LULC of 2011 has been simulated using past LULC maps of 1991 and 2001 and various influencing factors viz. distance from road (estimated from the road shapefile), distance from streams (estimated from river shapefile), elevation (estimated from relief map derived from DEM) and slopes (estimated from slope map derived from DEM). Afterwards, the simulated LULC map of 2011 has been compared with actual LULC map of 2011 prepared using TM image. Moreover, using the LULC of 2001 and 2011, LULC of 2021 has been predicted. The future land use change scenario has been discussed in section 4.3. 
Kumar S., Ghosh S., Hooda R.S., Singh S.: Monitoring and prediction of land use land cover changes and its impact on land surface temperature in the central part of Hisar district, Haryana under semi-arid zone of India

\section{RESULTS AND DISCUSSIONS}

\section{Area Change Analysis of LULC}

LULC maps of 1991, 2001 and 2011 have been obtained with six classes: built-up, forest/reserved area, grazing/grassland, agricultural land, vegetation, wasteland, and water bodies (Figure 3a-c). Subsequently, a quantitative analysis of the spatiotemporal change in the LULC of the study area has been performed from 1991 to 2001 and 2011 (Figure 3d, Table 2a). Moreover, to examine the conversion of one specific LULC class to another category at a later year, post classification matrices (Table $2 \mathrm{~b}-\mathrm{c}$ ) have been obtained. Such analysis has depicted a continuous and sharp increase in built up areas from $3.7 \%$ in 1991 to $5.0 \%$ and $6.2 \%$ in 2001 and 2011 respectively (Table 2a). The expansion of built-up region has taken place with the loss of fertile agricultural land to meet up the high demand for land for habitation and infrastructure development. Consequently, $14.1 \mathrm{~km}^{2}$ and $9.5 \mathrm{~km}^{2}$ agricultural area has been converted to built-up from 1991 to 2001 and 2011 respectively (Table 2b-c) and despite being the most dominant land cover class, agricultural land has shown a gradual and continuous decrease over the years $(87.6 \%$ in 1991, 86.9\% in 2001 and $86.3 \%$ in 2011). Although, a notable increase in area covering water bodies has been observed from the period of $1991(1.2 \%)$ to $2001(1.3 \%)$ and $2011(1.4 \%)$ which accounts for operation of wide-ranging canal network for irrigation purpose. Keeping pace with the expansion of urban settlement, rural settlement has also expanded by encroaching into the grazing land which has resulted into the decrease of grassland/ grazing lands from $2.1 \%$ in 1991 to $1.4 \%$ in 2011. On a positive note, it can be observed that some part of this land has also reclaimed and converted into agricultural land. Area coverage by waste land class comprising degraded scrub land, sandy waste and few waterlogged lands has maintained a decreasing trend over the study period. It is worthwhile to mention that some wastelands surrounding town have been utilized for urban expansion to avoid encroachment on productive and fertile agricultural areas which was identified in former study (Jain et al., 1991). Likewise, present study has revealed that $7.3 \mathrm{~km}^{2}$ and $13.1 \mathrm{~km}^{2}$ area of wasteland have been rejuvenated into agricultural land in the north-western portion of the study area during 1991-2001 and 2001-2011 respectively (Table 2b-c). Forest/reserved area class mostly comprises with thorn bush as well as those lands which has been reserved for forest plantation by the government. Although, this class exhibited a continuous decrease due to the clearance because of the expansion of the built-up areas, plantation and shrub has been found in the reserved areas due to the initiative by the government. 
Fig. 3: LULC maps of (a)1991, (b)2001 and (c)2011 and (d) Graphical representation of change in area occupied by different LULC in the observation periods.

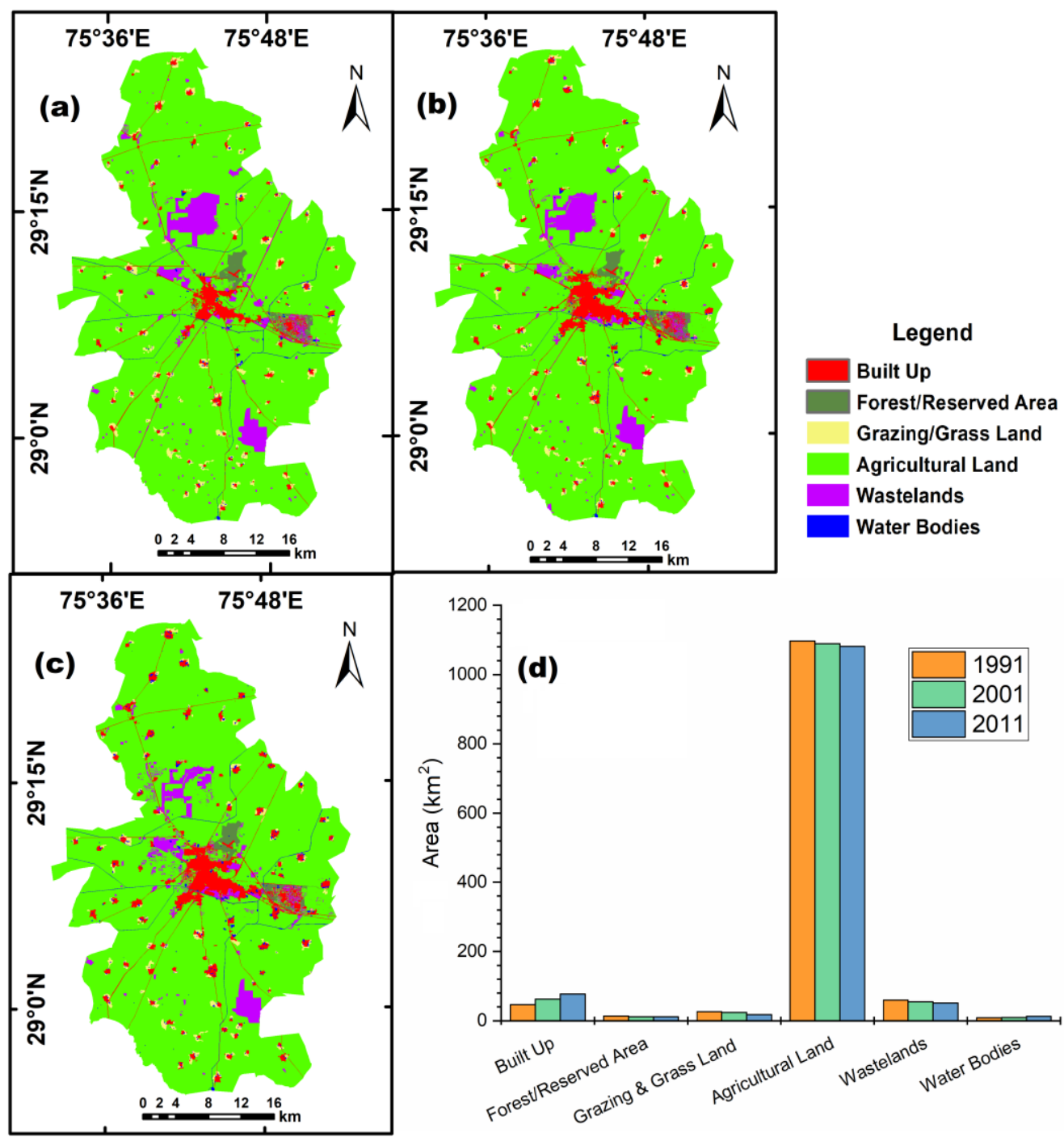


Kumar S., Ghosh S., Hooda R.S., Singh S.: Monitoring and prediction of land use land cover changes and its impact on land surface temperature in the central part of Hisar district, Haryana under semi-arid zone of India

Table 2a: Calculation of area under different LU/LC classes in 1991, 2001 and 2011

\begin{tabular}{|c|c|c|c|c|c|c|c|c|}
\hline & \multicolumn{3}{|c|}{ Area $\left(\mathrm{km}^{2}\right)$} & \multicolumn{3}{|c|}{ Area $(\%)$} & \multicolumn{2}{|c|}{ Percentage Change } \\
\hline LULC Classes & 1991 & 2001 & 2011 & 1991 & 2001 & 2011 & 1991-2001 & $2001-2011$ \\
\hline Water Bodies & 9.1 & 9.6 & 13.2 & 0.7 & 0.8 & 1.1 & 0.1 & 0.3 \\
\hline Agricultural Land & 1097 & 1089.1 & 1081.5 & 87.6 & 86.9 & 86.3 & -0.6 & -0.6 \\
\hline Forest/Reserved Area & 13.7 & 12 & 11.8 & 1.1 & 1.0 & 0.9 & -0.1 & 0.0 \\
\hline Built Up & 46.7 & 62.8 & 77.2 & 3.7 & 5.0 & 6.2 & 1.3 & 1.1 \\
\hline Grazing \& Grass & 26.4 & 24.3 & 17.9 & 2.1 & 1.9 & 1.4 & -0.2 & -0.5 \\
\hline Land & & & & & & & & \\
\hline Wastelands & 60.1 & 55 & 51.3 & 4.8 & 4.4 & 4.1 & -0.4 & -0.3 \\
\hline
\end{tabular}

*+ denotes positive change; - denotes negative change

Table 2b: Post classification matrix of study area from 1991 to 2001

Area $\left(\mathrm{km}^{2}\right)$ in 2001

\begin{tabular}{|c|c|c|c|c|c|c|c|}
\hline & LULC Classes & Built Up & $\begin{array}{c}\text { Forest/Reserved } \\
\text { Area }\end{array}$ & $\begin{array}{c}\text { Grazing } \\
\text { \& Grass } \\
\text { Land }\end{array}$ & $\begin{array}{l}\text { Agricultural } \\
\text { Land }\end{array}$ & Wastelands & $\begin{array}{l}\text { Water } \\
\text { Bodies }\end{array}$ \\
\hline \multirow{6}{*}{$\begin{array}{l}\text { Area }\left(\mathrm{km}^{2}\right) \\
\text { in } 1991\end{array}$} & Built Up & 44.5 & 0.0 & NS & 1.7 & NS & NS \\
\hline & $\begin{array}{l}\text { Forest/Reserved } \\
\text { Area }\end{array}$ & 0.0 & 10.9 & 0.0 & 2.7 & 0.0 & 0.0 \\
\hline & $\begin{array}{l}\text { Grazing \& Grass } \\
\text { Land }\end{array}$ & 1.1 & 0.0 & 24.0 & 1.1 & 0.0 & NS \\
\hline & $\begin{array}{l}\text { Agricultural } \\
\text { Land }\end{array}$ & 14.1 & 1.2 & 0.0 & 1076.0 & 5.5 & NS \\
\hline & Wastelands & 3.1 & 0.0 & NS & 7.3 & 49.4 & 0.0 \\
\hline & Water Bodies & 0.0 & 0.0 & 0.0 & NS & 0.0 & 8.8 \\
\hline
\end{tabular}

*NS: Not Significant

Table 2c: Post classification matrix of study area from 2001 to 2011

Area $\left(\mathrm{km}^{2}\right)$ in 2011

\begin{tabular}{|c|c|c|c|c|c|c|c|}
\hline & LULC Classes & Built Up & $\begin{array}{c}\text { Forest/Reserved } \\
\text { Area }\end{array}$ & $\begin{array}{c}\text { Grazing \& } \\
\text { Grass } \\
\text { Land }\end{array}$ & $\begin{array}{l}\text { Agricultural } \\
\text { Land }\end{array}$ & Wastelands & $\begin{array}{l}\text { Water } \\
\text { Bodies }\end{array}$ \\
\hline \multirow{3}{*}{$\begin{array}{l}\text { Area }\left(\mathrm{km}^{2}\right) \\
\text { in } 2001\end{array}$} & Forest/Reserved Area & NS & 9.7 & 0.0 & 1.9 & 0.0 & 0.0 \\
\hline & Grazing \& Grass Land & 4.4 & 0.0 & 17.9 & 0.0 & 0.0 & 2.1 \\
\hline & Agricultural Land & 9.5 & 1.9 & 0.0 & 1065.9 & 10.5 & 1.2 \\
\hline
\end{tabular}

*NS: Not Significant

For the accuracy assessment of the LULC maps, multi-spectral satellite images with better resolution than that of input images for the same years are not available. Therefore, the unclassified images for the three years have been used as reference images. The reference data for all the test pixels have been derived by visual interpretation of the reference image, field information, high-resolution Google Earth imageries and LU/ LC database available in 
the Bhuvan website. Total 500 pixels test pixels have been selected following a stratified random distribution. Errors of omission, errors of commission, user's accuracy and producer's accuracy have been calculated for each class for the three LULC maps of 1991, 2001 and 2011. The overall classification accuracy has been observed as $90.2 \%, 90.6 \%$ and $88.6 \%$ and Kappa coefficient has been calculated as $0.86,0.87$ and 0.84 of the of the classified output of 1991, 2001 and 2011 respectively. The values of individual accuracies in terms of user's and producer's accuracies range from $77 \%$ to $98 \%$ in 1991 while $72 \%$ to $100 \%$ in 2001 and $68 \%$ to $100 \%$ in 2011. A more careful observation at the error matrix notices that there is some misclassification between grazing/grassland and agricultural land which pertains to spectral similarity of these two classes at few places in the study area. Likewise, the issue of mixed pixel of grazing land and rural built up because of their close occurrence could be a reason of lower accuracy of grazing/grassland class (Table 3a-c).

Table 3a: Error matrix for the mapping of LU/LC (1991)

\begin{tabular}{|c|c|c|c|c|c|c|c|c|}
\hline \multicolumn{9}{|c|}{ Reference data } \\
\hline Classified data & $\begin{array}{l}\text { Water } \\
\text { Bodies }\end{array}$ & $\begin{array}{l}\text { Agricultu } \\
\text { Land }\end{array}$ & $\begin{array}{l}\text { Forest } \\
\text { /Reserved } \\
\text { area }\end{array}$ & Buitl-up & Grazing/Grassland & Wasteland & $\begin{array}{l}\text { Total } \\
\text { pixels }\end{array}$ & $\begin{array}{l}\text { User's } \\
\text { accuracy } \\
(\%)\end{array}$ \\
\hline Water Bodies & 41 & 6 & 0 & 1 & 2 & 0 & 50 & 82.00 \\
\hline Agricultural Land & 0 & 228 & 0 & 2 & 0 & 2 & 232 & 98.28 \\
\hline Forest/Reserved area & 0 & 5 & 40 & 1 & 0 & 5 & 51 & 78.43 \\
\hline Built-up & 0 & 2 & 0 & 47 & 1 & 6 & 56 & 83.93 \\
\hline Grazing/Grassland & 1 & 7 & 0 & 4 & 41 & 0 & 53 & 77.36 \\
\hline Wasteland & 0 & 2 & 1 & 1 & 0 & 54 & 58 & 93.10 \\
\hline Total pixels & 42 & 250 & 41 & 56 & 44 & 67 & 500 & \\
\hline $\begin{array}{l}\text { Producer's accuracy } \\
(\%)\end{array}$ & 97.62 & 91.20 & 97.56 & 83.93 & 93.18 & 80.60 & & \\
\hline
\end{tabular}

Table 3b: Error matrix for the mapping of LU/LC (2001)

\begin{tabular}{|c|c|c|c|c|c|c|c|c|}
\hline \multicolumn{9}{|c|}{ Reference data } \\
\hline Classified data & $\begin{array}{l}\text { Water } \\
\text { Bodies }\end{array}$ & $\begin{array}{l}\text { Agricultu } \\
\text { Land }\end{array}$ & $\begin{array}{l}\text { Forest } \\
\text { /Reserved } \\
\text { area }\end{array}$ & Buitl-up & Grazing/Grassland & Wasteland & $\begin{array}{l}\text { Total } \\
\text { pixels }\end{array}$ & $\begin{array}{l}\text { User's } \\
\text { accuracy } \\
(\%)\end{array}$ \\
\hline Water Bodies & 40 & 6 & 0 & 4 & 0 & 0 & 50 & $80.00 \%$ \\
\hline Agricultural Land & 0 & 221 & 1 & 1 & 1 & 7 & 231 & $95.67 \%$ \\
\hline Forest/Reserved area & 0 & 0 & 45 & 2 & 0 & 3 & 50 & $90.00 \%$ \\
\hline Built-up & 0 & 4 & 0 & 54 & 1 & 0 & 59 & $91.53 \%$ \\
\hline Grazing/Grassland & 0 & 3 & 0 & 8 & 41 & 0 & 52 & $78.85 \%$ \\
\hline Wasteland & 0 & 1 & 0 & 5 & 0 & 52 & 58 & $89.66 \%$ \\
\hline Total pixels & 40 & 235 & 46 & 74 & 43 & 62 & 500 & \\
\hline Producer's accuracy $(\%)$ & 100.00 & $94.04 \%$ & $97.83 \%$ & $72.97 \%$ & $95.35 \%$ & $83.87 \%$ & & \\
\hline
\end{tabular}

Table 3c: Error matrix for the mapping of LU/LC (2011)

\begin{tabular}{|c|c|c|c|c|c|c|c|c|}
\hline \multicolumn{9}{|c|}{ Reference data } \\
\hline Classified data & $\begin{array}{l}\text { Water } \\
\text { Bodies }\end{array}$ & $\begin{array}{l}\text { Agricultural } \\
\text { Land }\end{array}$ & $\begin{array}{l}\text { Forest } \\
\text { /Reserved } \\
\text { area } \\
\end{array}$ & Buitl-up & $\begin{array}{l}\text { Grazing/ } \\
\text { Grassland }\end{array}$ & Wasteland & $\begin{array}{l}\text { Total } \\
\text { pixels }\end{array}$ & $\begin{array}{l}\text { User's } \\
\text { accuracy } \\
(\%)\end{array}$ \\
\hline Agricultural Land & 0 & 228 & 0 & 0 & 0 & 3 & 231 & $98.70 \%$ \\
\hline Forest/Reserved area & 0 & 1 & 46 & 1 & 0 & 2 & 50 & $92.00 \%$ \\
\hline Built-up & 0 & 3 & 1 & 54 & 0 & 3 & 61 & $88.52 \%$ \\
\hline Total pixels & 39 & 261 & 48 & 67 & 38 & 47 & 500 & \\
\hline Producer's accuracy (\%) & $100.00 \%$ & $87.36 \%$ & $95.83 \%$ & $80.60 \%$ & $97.37 \%$ & $82.98 \%$ & & \\
\hline
\end{tabular}


Kumar S., Ghosh S., Hooda R.S., Singh S.: Monitoring and prediction of land use land cover changes and its impact on land surface temperature in the central part of Hisar district, Haryana under semi-arid zone of India

\section{Variation of LST with respect to LULC and Spectral Indices}

The LST maps generated for the month of March in 1991, 2001 and 2011 have revealed that mean LST has exhibited a notable increase $\left(5.4^{\circ} \mathrm{C}\right)$ from $23.31^{\circ} \mathrm{C}$ to $28.67{ }^{\circ} \mathrm{C}$ from 1991 to 2001. The minimum and maximum temperature has also increased from 1991 (minimum temperature- $17.02{ }^{\circ} \mathrm{C}$, maximum temperature-29.59 ${ }^{\circ} \mathrm{C}$ in 1991) to 2001 (minimum temperature- $19.72{ }^{\circ} \mathrm{C}$, maximum temperature- $37.61{ }^{\circ} \mathrm{C}$ in March 2001 ). In contrast to such significant increase in LST, a slight decrease in minimum $\left(18.83{ }^{\circ} \mathrm{C}\right)$, maximum $\left(35.65{ }^{\circ} \mathrm{C}\right)$ and mean $\operatorname{LST}\left(27.24^{\circ} \mathrm{C}\right)$ has been observed in 2011 from the prior observation periods (Figure 4a-c). However, to analyse the impact of conversion of LULC over the variation thermal condition in the study area, mean LST has been associated with different LULC types, with error bars representing \pm 1 standard deviation of each type (Figure $4 \mathrm{~d})$. The difference between average LST for built up and non-built up area $\left(22.8^{\circ} \mathrm{C}\right.$ and $22.2^{\circ} \mathrm{C}$ in $1991,29.2{ }^{\circ} \mathrm{C}$ and $28.2^{\circ} \mathrm{C}$ in $2001,26.3^{\circ} \mathrm{C}$ and $25.7^{\circ} \mathrm{C}$ in 2011 ) has exhibited an increase-decrease pattern from 1991 to 2001 and to 2011 respectively. Compared to other LULC types, wasteland exhibits the highest mean LST values in all the three observation periods $\left(24.2{ }^{\circ} \mathrm{C}\right.$ in $1991,30.8{ }^{\circ} \mathrm{C}$ in $2001,28.2{ }^{\circ} \mathrm{C}$ in 2011$)$ because of huge amount heat being released by sandy waste, salt affected area and brick-kiln included in this category. In contrast to the prior works conducted in the neighbouring region of the study area where higher LST has been reported in the city core than the rural surrounding (Kikon et al., 2016), in the present research, grazing land and sandy waste especially the bare land located in rural surrounding exhibits higher temperature compared to city core (Table 4). Such a situation pertains to reduced evapotranspiration because of scanty vegetation cover in the rural surrounding during dry pre-monsoon summer. Presence of bare land in the form of fallow area, overgrazed land, lower moisture holding ability of thorny bushes are the dominant factors for the reduced evaporative cooling in the semi-arid regions (Fan et al., 2017; Shastri et al., 2017). Moreover, green cover in the form of parks, and plantation in the city becomes important contributor to lower mean LST because of high rates of evapotranspiration which has been termed 'oasis effect' in the cities located in the arid and semi-arid in earlier studies (Fan et al., 2017). Although, built-up area comprising high-rise buildings, roadways, industrial area with other constructions has also been detected with high mean LST because of the trapping of radiation and release of human-induced heat. However, agricultural land has been detected with low mean LST as agricultural lands with comparatively consistent land surface material are far away from city core avoiding the influence of urban heat (Yue et al., 2007).

Table 4: Mean LST under different LU/LC classes in 1991, 2001 and 2011

\begin{tabular}{lccc}
\hline LU/LC Classes & 1991 & 2001 & 2011 \\
& & & \\
\hline Water Bodies & 20.48 & 25.71 & 23.30 \\
Agricultural Land & 21.03 & 26.24 & 23.92 \\
Forest/Reserved Area & 21.97 & 28.58 & 26.55 \\
Built Up & 22.79 & 29.17 & 26.38 \\
Grazing \& Grass Land & 23.21 & 29.74 & 26.76 \\
Wastelands & 24.21 & 30.82 & 28.19 \\
\hline
\end{tabular}


Fig. 4: LST maps of (a)1991, (b)2001 and (c)2011 and (d) Graphical representation of mean values of LST associated with different LULC in the observation periods.

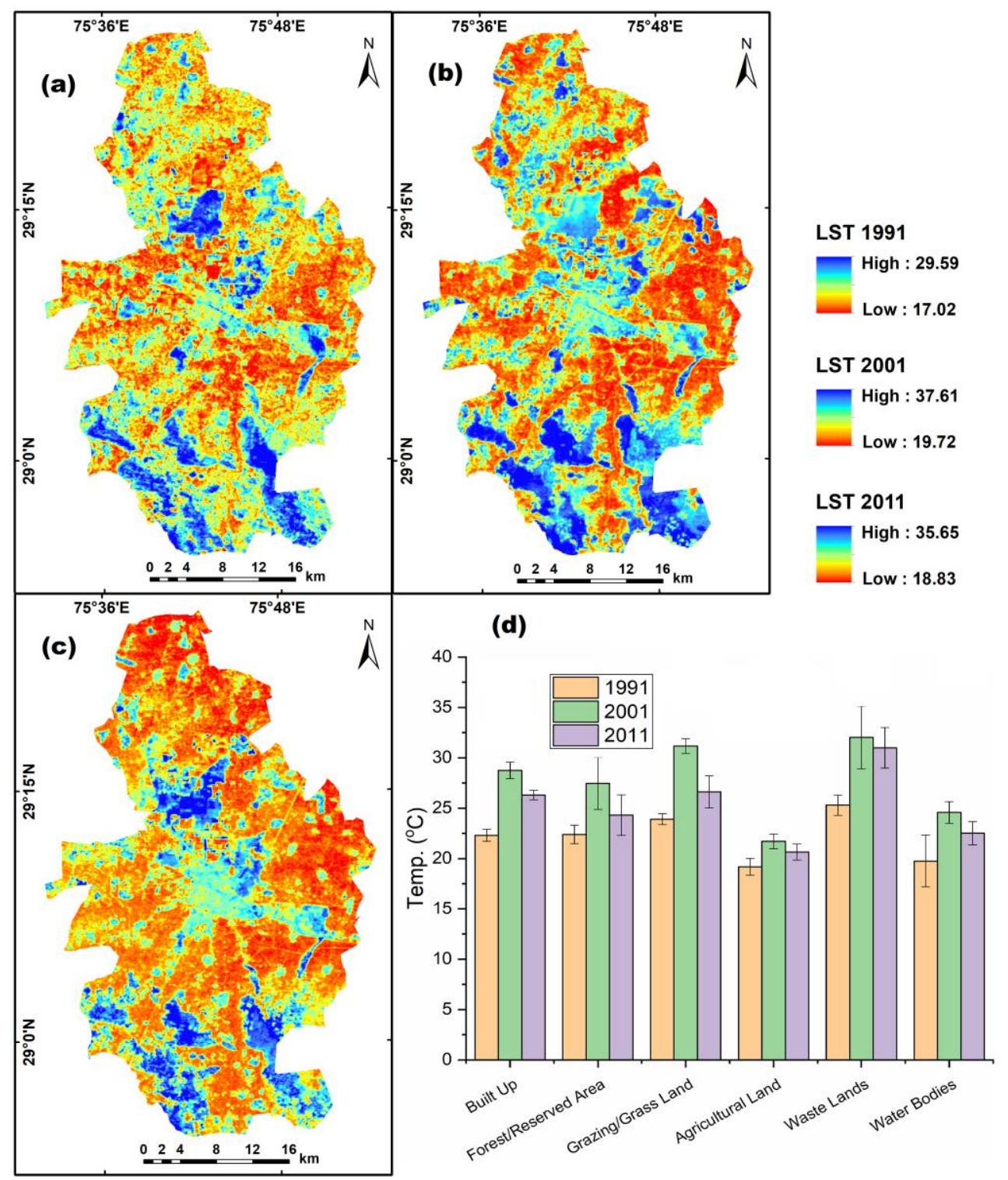

The minimum and maximum NDVI values in 1991 (minimum: -0.38 and maximum: 0.73), 2001 (minimum: -0.32 and maximum: 0.73) and 2011 (minimum: -0.27 and maximum: 0.74) has depicted stable maximum NDVI value over the study periods which indicated a decreasing trend of green space over the study area (Figure 5a-c). According to the India State of Forest Report 2011, only $1.05 \%$ of total geographical area is under forest cover in Hisar Tehsil standing after Fatehabad $(0.71 \%)$ and Sonipat $(0.99 \%)$. Looking into the NDBI maps, it has been observed that NDBI values $>0$ are associated mainly with the built-up in the central urban core. In southern part of the study area, high NDBI of the areas where waste 
Kumar S., Ghosh S., Hooda R.S., Singh S.: Monitoring and prediction of land use land cover changes and its impact on land surface temperature in the central part of Hisar district, Haryana under semi-arid zone of India

land and fallow land exists (Figure 6a-c). In the regression analysis between mean LST and mean NDVI for 1991, 2001 and 2011, considering entire study area, y-axis represents mean LST associated with different LULC class and x-axis represents mean NDVI values (Figure 5d). Each point represents the mean LST and NDVI value in each zone (different coloured points (red for 1991, green for 2001 and blue for 2011) have been used for designating three different years), different coloured lines (as expressed in the legend of figure 5d) has been used to represent the result of linear simulation for the three different years and regression functions are also exhibited in Table 5. Similar regression analysis between mean LST and mean NDBI for the three years has been represented in figure $6 \mathrm{~d}$. As more than $85 \%$ of the study area is covered with agricultural lands, large number of points in the regression analysis have depicted stable mean LST with considerable variation of NDVI which may suggest that NDVI values changes significantly depending upon the density of agricultural land but LST has not changed much. Overall, the regression analysis for the three dates exhibited a strong negative correlation (Pearson's $r$ value -0.79 in 1991, -0.87 in 2001 and -.0.84 in 2011) between mean LST and mean NDVI depicting areas with high NDVI values with lower LST and vice-versa. In contrast, another regression analysis between mean LST and mean NDBI values for the three observation periods exhibited a strong positive correlation (Pearson's r value 0.84 in 1991, 0.89 in 2001 and 0.79 in 2011) between mean LST and mean NDBI depicting areas with high NDBI values with higher LST and vice-versa (Figure 6d). Similar observations have been reported by a few previous studies (Tran et al., 2017; Kikon et al., 2016). Looking into such observations, it can be remarked that higher NDVI associated with more vegetation cover corresponds to high rate of evapotranspiration leading to exchange of heat between surface and atmosphere (Yue et al., 2007). Therefore, utilization of suitable sites for urban green cover should be encouraged by the policy maker in case of town and city planning to control the urban heat effect.

Table 5: Linear regression and correlation coefficients for the relationship between Spectral Indices and Mean LST in 1991, 2001 and 2011

\begin{tabular}{|c|c|c|c|c|c|c|}
\hline & \multicolumn{3}{|c|}{ NDVI and LST } & \multicolumn{3}{|c|}{ NDBI and LST } \\
\hline & 1991 & 2001 & 2011 & 1991 & 2001 & 2011 \\
\hline $\begin{array}{l}\text { Regression } \\
\text { Functions }\end{array}$ & $y=-7.97 x+23.81$ & $y=-14.96 x+31.26$ & $y=-13.47 x+29.52$ & $y=8.97 x+21.37$ & $y=16.94 x+26.65$ & $y=11.95 x+24.22$ \\
\hline Pearson's r & -0.79 & -0.87 & -0.84 & 0.84 & 0.89 & 0.79 \\
\hline
\end{tabular}


Fig. 5: NDVI maps of (a)1991, (b)2001 and (c)2011 and (d) Scatter plot linear regression of NDVI and mean LST during different observation periods.

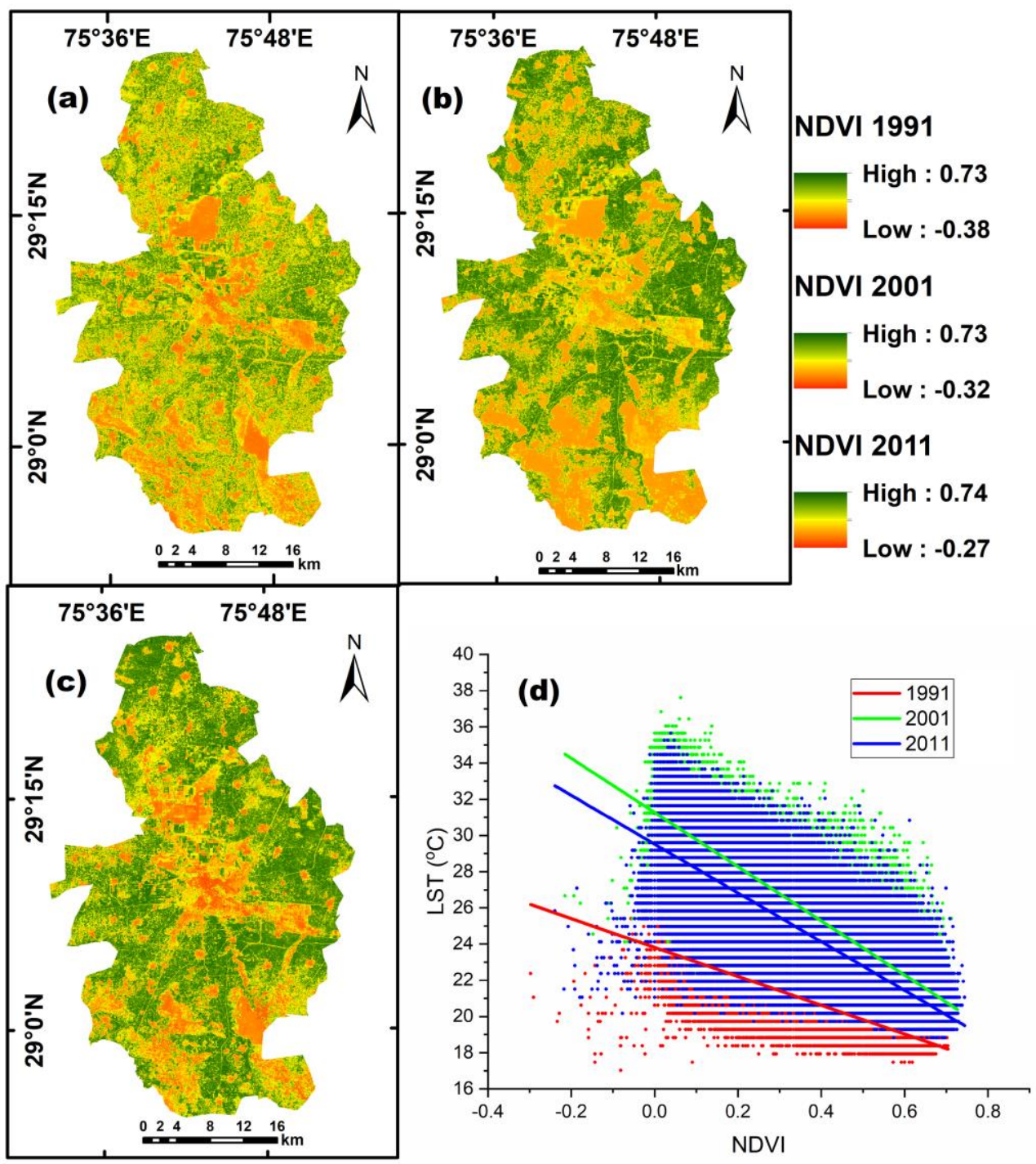


Fig. 6: NDBI maps of (a)1991, (b)2001 and (c)2011 and (d) Scatter plot linear regression of NDBI and mean LST during different observation periods.

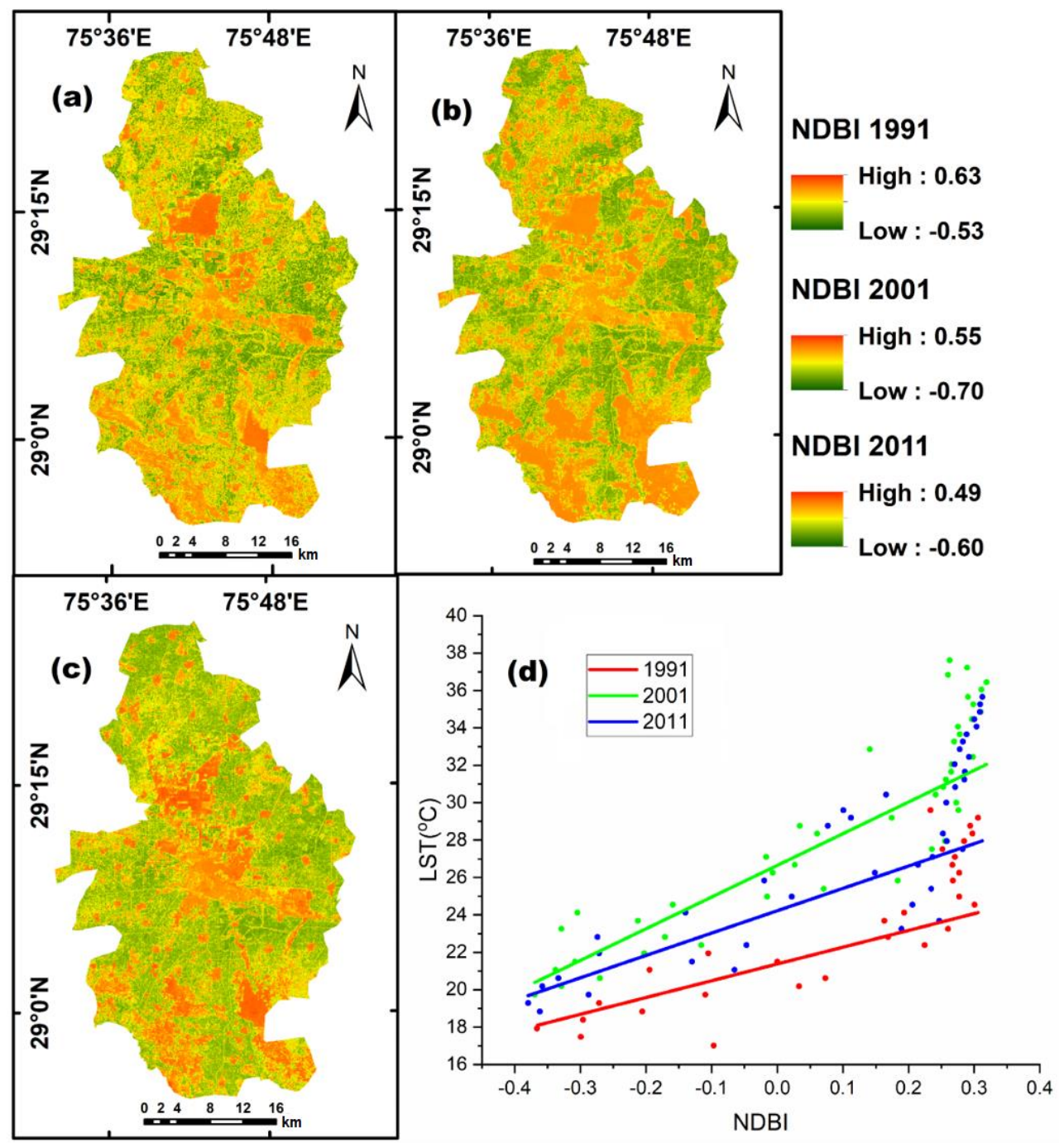

\section{Prediction, Validation and Analysis of Future LULC}

The transitional probability matrix (TPM) (Table 6) has been produced through LCM by examining LULC maps 1991 and 2001 to predict the land use map for 2011 (simulated map). In TPM, except for the transition probabilities of similar land uses together, the transition probabilities of forest to agricultural land, i.e. 0.20 is the highest probabilities. It has been further validated by comparing observed and simulated LULC maps of 2011 (Figure 7 a and b; Table 7). A visual interpretation of the simulated and actual maps for the year 2011 has exhibited adequate similarity between the predicted result and the actual LULC type. Although, a noticeable mismatch has been observed in case of the area coverage by agricultural land (observed area-1081.49 $\mathrm{km}^{2}$, simulated area-1075.34 km²). Such difference 
in area has been observed due to establishment of Ramdhan Singh farm in this area after 2002. In figure $7 d$, the enlarged view of the mentioned discrepancy (marked using the black circle in figure 7a and b) has been displayed. Both in the LULC maps of 1991 and 2001, the marked area has been identified as wasteland, therefore, in the simulated LULC map of 2011 that area has been predicted as wasteland as no change has been observed between landcover classes in the input years (i.e. 1991 and 2001) which has been used to predict the landcover of 2011. Therefore, it can be remarked that LCM can be used in predicting future LULC change with the premise of having uniform rate of change in the future (Yirsaw et al., 2017).

Table 6: Transitional Probability Matrix to 2011 based on LU/LC maps of 1991 and 2001

\begin{tabular}{|c|c|c|c|c|c|c|}
\hline & $\begin{array}{l}\text { Water } \\
\text { Bodies }\end{array}$ & Agricultural Lanı & $\begin{array}{l}\text { Forest } \\
\text { /Reserved } \\
\text { area }\end{array}$ & Buitl-up & Grazing/Grassland & Wasteland \\
\hline Water Bodies & 0.981 & 0.011 & 0 & 0.002 & 0.003 & 0.004 \\
\hline Agricultural Land & 0 & 0.973 & 0.001 & 0.013 & 0 & 0.012 \\
\hline Forest/Reserved area & 0.001 & 0.206 & 0.793 & 0 & 0 & 0 \\
\hline Built-up & 0.001 & 0.006 & 0.003 & 0.95 & 0.002 & 0.005 \\
\hline Grazing/Grassland & 0.008 & 0.041 & 0 & 0.04 & 0.911 & 0 \\
\hline Wasteland & 0 & 0.049 & 0 & 0.045 & 0.003 & 0.903 \\
\hline
\end{tabular}

Table 7: Difference in area coverage under different LU/LC classes between observed and simulated LU/LC maps of 2011

\begin{tabular}{lcc}
\hline & \multicolumn{2}{c}{ Area $\left(\mathrm{km}^{2}\right)$} \\
\hline LU/LC Classes & Observed & Simulated \\
\hline Water Bodies & 13.24 & 11.58 \\
Agricultural Land & 1081.49 & 1075.34 \\
Forest/Reserved Area & 11.79 & 11.63 \\
Built Up & 77.17 & 79.07 \\
Grazing \& Grassland & 17.91 & 22.35 \\
Wastelands & 51.25 & 52.86 \\
\hline
\end{tabular}

In TPM for 2021 (Table 8) the transition probabilities of grazing/grassland class and wasteland class to built-up and agricultural land, i.e. 0.18 and 0.21 respectively, are the highest probabilities. The transition probability of the built-up class to that same category is greater than the transition to other categories, which indicates the growth of built-up region. Though, some land use transition in TPM appears to be irrational (i.e. the transition of built-up to waterbodies) which could be attributed to the minor errors in land use classification. Based on the predicted LULC map of 2021 (Figure 7c), significant increase in built-up area from 2011 to 2021 can be predicted (6.2\% in 2011 whereas $7.5 \%$ in 2021) may be at the cost of wasteland (4.1\% in 2011 whereas $3.0 \%$ in 2021), grazing and grassland ( $1.4 \%$ in 2011 whereas $1.0 \%$ in 2021) as a noticeable decrease in these classes is also projected. Such scenario could be anticipated due to housing and infrastructure development because of the expansion of Hisar city around and along the NH-65. 
Kumar S., Ghosh S., Hooda R.S., Singh S.: Monitoring and prediction of land use land cover changes and its impact on land surface temperature in the central part of Hisar district, Haryana under semi-arid zone of India

Fig. 7: LULC maps of (a)2011 (observed), (b)2011 (predicted), (c)2021 (predicted) (d) Enlarged view of the discrepancies (marked by black circle in (a) and (b)) between LULC maps of 2011 (observed and predicted) (black circle area shows agricultural land as observed LULC in 2011 and wasteland as predicted LULC in 2011)

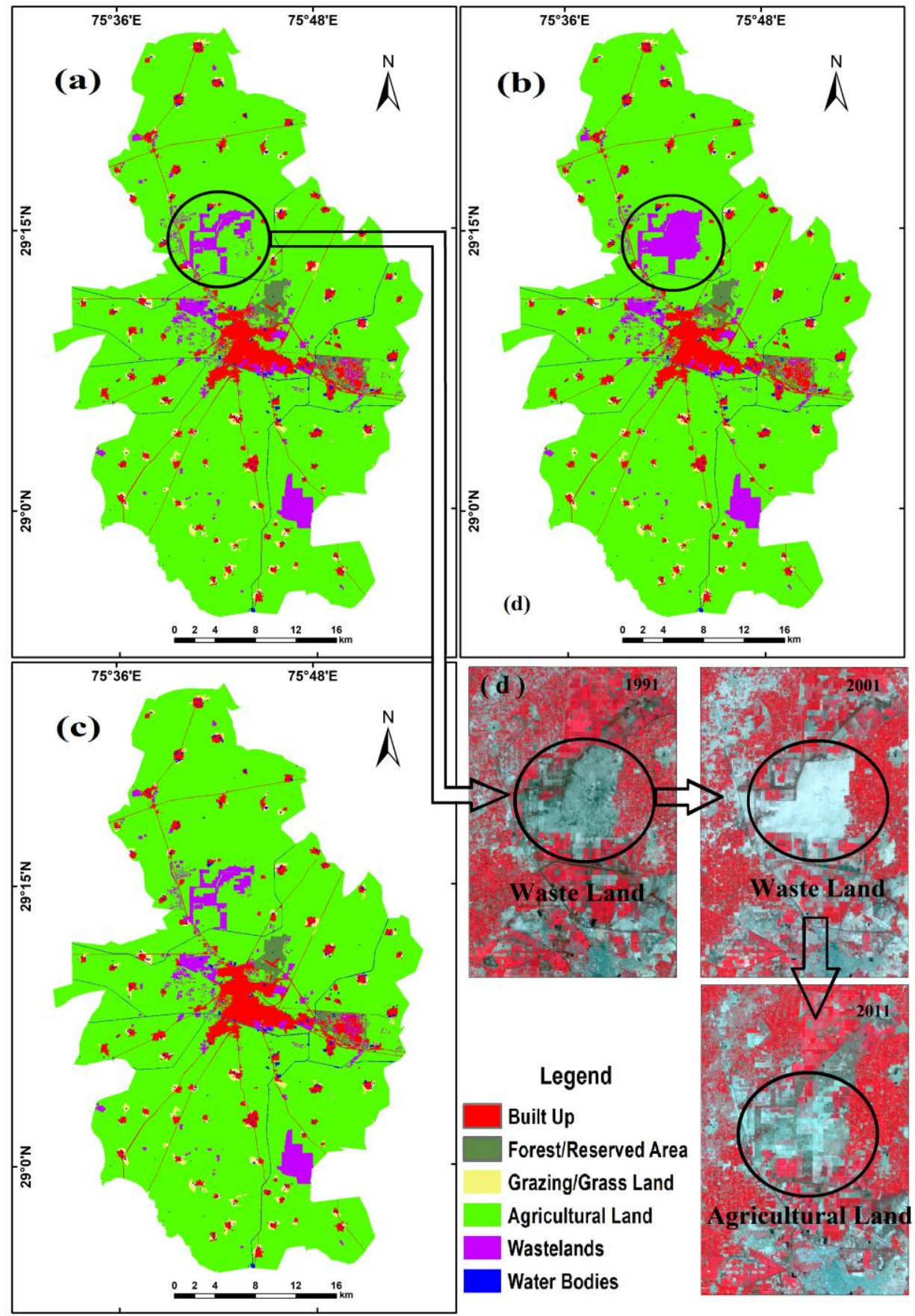


Results of the present study has confirmed the hypothesis that urban growth affecting the pattern of LULC in the form of loss of agricultural land. Moreover, concrete building, industrial area in the urbanized region has been hypothesized as a reason of trapping heat and thereby raise the temperature there compared to the rural side. Conversely, the present study has identified higher LST over the rural surrounding compared to the main city area. The presence of sandy waste, salt affected area and brick-kiln and enormous heat released by them lead to higher LST in the countryside.

Table 8: Transitional Probability Matrix to 2021 based on LU/LC maps of 2001 and 2011

\begin{tabular}{lllllll}
\hline & $\begin{array}{l}\text { Water } \\
\text { Bodies }\end{array}$ & Agricultural Land & $\begin{array}{l}\text { Forest } \\
\text { /Reserved } \\
\text { area }\end{array}$ & Buitl-up & Grazing/Grassland & Wasteland \\
\hline Water Bodies & 0.957 & 0.008 & 0 & 0.031 & 0.004 & 0 \\
Agricultural Land & 0 & 0.98 & 0 & 0.009 & 0 & 0.011 \\
Forest/Reserved area & 0.003 & 0 & 0.979 & 0.018 & 0.001 & 0 \\
Built-up & 0.011 & 0 & 0 & 0.99 & 0 & 0 \\
Grazing/Grassland & 0.086 & 0 & 0 & 0.18 & 0.734 & 0 \\
Wasteland & 0.003 & 0.217 & 0 & 0.027 & 0 & 0.754 \\
\hline
\end{tabular}

\section{CONCLUSIONS}

Despite the rapid urbanization and population growth, Hisar tehsil has been rarely inspected regarding its urban expansion and its associated impact. To overcome the data-scarcity in this region, the present study has attempted the spatio-temporal pattern analysis of LULC change using the satellite images of 1991, 2001 and 2011 with the prediction of future land use of 2021 and impact of such land use dynamics over its thermal environment. The present study area has experienced a major increase in the built-up zone at the cost of fertile agricultural which can hamper the economy as the area is mostly agriculture dominated. Although, on a positive note, it can be observed that some of the wastelands have been utilized for the development of residential area and few wasteland areas have been revived for agriculture with proper measures. Moreover, Government initiatives have been taken for reserving some land for plantation purposes. Despite of such precautions and corrective measures, the residential and infrastructural development to fulfil the urban need possess notable impact over thermal environment. Variation of LST with respect to different LULC revealed that built-up zone has exhibited high temperature because of heat-trapping characteristics of material used for making high-rise building and other construction related to industrial, infrastructural setup. Although, compared to city core, higher temperature has been observed in some parts sandy waste, salt-affected region and grazing land in surrounding rural region because of thorny bushes and sparse pre-monsoon vegetation and thereby reduced evaporative cooling. On the other side, urban green space contributes to reduce the temperature in the city region producing the 'oasis effect' in the study area located in the semi-arid climatic zone. Correlation analysis between the mean LST and spectral indices revealed that more vegetation cover corresponds to high rate of evapotranspiration leading to exchange of heat between surface and atmosphere and thus could be a measure of controlling increase of temperature. Based on the obtained results, it can be certainly remarked that this research could be useful proper urban planning and environmental management for sustainable urban development. 
Kumar S., Ghosh S., Hooda R.S., Singh S.: Monitoring and prediction of land use land cover changes and its impact on land surface temperature in the central part of Hisar district, Haryana under semi-arid zone of India

\section{REFERENCES}

Almalki, K. A., \& Al-Namazi, A. A. (2019). Impact of the industrial sector on surface temperatures in Jubail City, Saudi Arabia using remote sensing techniques. Spatial Information Research, 27(3), 329-337.

Ansari, A., \& Golabi, M. H. (2019). Prediction of spatial land use changes based on LCM in a GIS environment for Desert Wetlands - A case study: Meighan Wetland, Iran. International Soil and Water Conservation Research, 7(1), 64-70.

Artis, D.A. and Carnahan, W.H. (1982). Survey of emissivity variability in thermography of urban areas. Remote Sensing of Environment, 12, 313-329.

Card, D. H. (1982). Using known map categorical marginal frequencies to improve estimates of thematic map accuracy. Photogrammetric Engineering and Remote Sensing, 48 (3), 431439.

Carlson, T.N., Ripley, D.A., 1997. On the relation between NDVI, fractional vegetation cover, and leaf area index. Remote Sens. Environ. 62, 241-252

Congalton, R. G. (1991). A review of assessing the accuracy of classifications of remotely sensed data. Remote Sensing of Environment 37(1), 35-46.

De Sherbinin, A., Schiller, A. and Pulsipher, A. (2007). The vulnerability of global cities to climate hazards. Environment and Urbanization, 19, 39-64.

Dou, P. and Chen, Y. (2017). Dynamic monitoring of land-use/land-cover change and urban expansion in Shenzhen using Landsat imagery from 1988 to 2015, International Journal of Remote Sensing, 38 (19), 5388-5407.

Duan, S.-B., Li, Z.-L. Wang, C., Zhang, S., Tang, B.-H., Leng, P. \& Gao, M.-F. (2019). Land-surface temperature retrieval from Landsat 8 single- channel thermal infrared data in combination with NCEP reanalysis data and ASTER GED product. International Journal of Remote Sensing, 40 (5-6), 1763-1778.

Estoque, R.C., Murayama, Y., Myint, S.W., (2017). Effects of landscape composition and pattern on land surface temperature: an urban heat island study in the megacities of Southeast Asia. Science of the Total Environment, 577, 349-359.

Fan, C., Myint, S., Kaplan, S., Middel, A., Zheng, B., Rahman, A., Huang, H.P., Brazel, A. and Blumberg, D., (2017). Understanding the impact of urbanization on surface urban heat islands - a longitudinal analysis of the oasis effect in subtropical desert cities. Remote Sensing, 9(7), p.672.

Gibson, L., Munch, Z., Palmer, A., and Mantel, S. (2018). Future land cover change scenarios in South African grasslands e implications of altered biophysical drivers on land management. Heliyon 4 (2018) e00693.

Gober, P., Brazel, A., Quay, R., Myint, S., Grossman-Clarke, S., Miller, A., Rossi, S., (2009). Using watered landscapes to manipulate urban heat island effects: how much water will it take to cool Phoenix? Journal of the Americal Planning and Association 76 (1), 109-121.

Government of India (GOI), (2011). Census of India 2011: Towards a bright future. Registrar General and Census Commissioner of India, Ministry of Home Affairs, New Delhi, India.

Herold, M., Couclelis H. and K. C. Clarke, (2005). The Role of Spatial Metrics in the Analysis and Modeling of Urban Land Use Change. Computer, Environment and Urban Systems, 29 (4), 369-399. 
Hondula, D.M., Davis, R.E., Leisten, M.J., Saha, M.V., Veazay, L.M. and Wegner, C.R. (2012). Finescale spatial variability of heat-related mortality in Philadelphia County, USA, from 1983-2008: a case-series analysis. Environmental Health 11 (1), 1-11.

Imam, A.U. and Banerjee, U.K. (2016). Urbanisation and greening of Indian cities: Problems, practices, and policies. Ambio, 45(4), 442-457.

Islam K., Jashimuddin, M., Nath, B. and Nath, T.K. (2018). Land use classification and change detection by using multi-temporal remotely sensed imagery: The case of Chunati wildlife sanctuary, Bangladesh. The Egyptian Journal of Remote Sensing and Space Science, 21 (1), 37-47.

Jain, A.K., Hooda, R.S., Nath, J. and Manchanda, M.L. (1991). Mapping and Monitoring of Urban Landuse of Hisar Town, Haryana Using Remote Sensing Techniques. Journal of the Indian Sodety of Remote Sensing, 19(2), 125-134.

Kaushik, V., Saroj, Sharma M.P., Hooda R.S. (2016). Land Use / Land Cover Change detection by Using Geo-Spatial Techniques of Hisar city Haryana (India). International Journal of Science, Engineering and Technology Research, 4(4), 672-676.

Kayet, N., Pathak, K., Chakrabarty, A. and Sahoo, S. (2016). Spatial impact of land use/land cover change on surface temperature distribution in Saranda Forest, Jharkhand. Modeling Earth Systems and Environment 2, 127.

Kikon, N., Singh, P. and Singh, S.K. and Vyas, A. (2016). Assessment of urban heat islands (UHI) of Noida City, India using multi-temporal satellite data. Sustainable Cities and Society, 22, 19-28.

Kolb, M., Mas, J.F., Galicia, L., (2013). Evaluating drivers and transition potential models in a complex landscape in southern Mexico. International Journal of Geographical Information Science, 27 (9), 1804-1827.

Kumar, P., Kumar, S. and Shekhar, C., (2016). Urban Sprawl of Hisar city using Remote sensing \& GIS - A case study. International Journal of Science, Engineering and Technology Research, 5(5), 1762-1767.

Lo, C.P., Quattrochi, D.A. and Luvall, J.C., (1997). Application of high-resolution thermal infrared remote sensing and GIS to assess the urban heat island effect. International Journal of Remote Sensing, 18, pp. 287-303.

Luck, M., Wu, J.G. (2002). A gradient analysis of urban landscape pattern: a case study from the Phoenix metropolitan region, Arizona, USA. Landsc Ecol 17(4):327-339.

Markham, B.L. \& Barker, J.L. (1986). Landsat MSS and TM post-calibration dynamic ranges, exoatmosphericreflectances and at-satellite temperatures. EOSAT Landsat Technical Notes, 1, 3-8.

Newbold, K.B., and Scott, D. (2013). Migration, commuting distance, and urban sustainability in Ontario's Greater Golden Horseshoe: Implications of the Greenbelt and Places to Grow legislation. Can. Geogr., 57(4), 474-487.

Rajesh (2018). Land use land cover thematic mapping using remote sensing \& GIS Techniques: A case study of district Hisar. International Journal of Applied Research,4(7), 6-10.

Ramachandra, T.V., Kumar, U., (2008). Wetlands of greater Bangalore, India: automatic delineation through pattern classifiers. Electronic Green Journal (26), Spring.

Ramachandra, T.V., Aithal, B., Durgappa S (2012). Insights to urban dynamics through landscape spatial pattern analysis. International Journal of Applied Earth Observation and 
Kumar S., Ghosh S., Hooda R.S., Singh S.: Monitoring and prediction of land use land cover changes and its impact on land surface temperature in the central part of Hisar district, Haryana under semi-arid zone of India

Geoinformation 18 (2012), 329-343.

Riffat, S., Powell, R. and Aydin, D. (2016). Future cities and environmental sustainability. Future Cities and Environment, 2, 1.

Rodriguez-Galiano, V, Chica-Olmo, M. (2012). Land cover change analysis of a Mediterranean area in Spain using different sources of data: multi-seasonal Landsat images, land surface temperature, digital terrain models and texture. Applied Geography, 35(1):208218.

Shashikant, Singh, P., Doi, R.D., Sharma, A., Kumar, R., Bhatti, P. (2015). Urban Sprawl and Spatio Temporal Analysis of Hisar City in Haryana using Remote Sensing \& GIS Technology. International Journal of Science, Engineering and Technology Research, 4 (12), 4388-4392.

Shastri, H., Barik, B., Ghosh, S., Venkataraman C. and Sadavarte, P. (2017). Flip flop of Day-night and SummerWinter Surface Urban Heat Island Intensity in India. Scientific reports, $7,40178$.

Sobrino, J.A., Jiménez-Muñoz, J.C., Paolini, L., (2004). Land surface temperature retrieval from LANDSAT TM 5. Remote Sens. Environ. 90 (4), 434-440.

Tewolde, M.G.; Cabral, P (2011). Urban sprawl analysis and modelling in Asmara, Eritrea. Remote Sensing, 3, 2148-2165.

Tran, D.X., Pla, F., Carmona, P.L., Myint, S.W., Caetano, M. and Kieu, H.V. (2017). Characterizing the relationship between land use land cover change and land surface temperature. ISPRS Journal of Photogrammetry and Remote Sensing, 124, 119-132.

UNFPA (United Nations Population Fund), (2009). Annual Report 2008, pp.44.

United Nations (2018). The 2018 Revision of World Urbanization Prospects. New York: UN.

Wang, Y.-C., Hu, B.K.H., Myint, S.W., Feng, C.-C., Chow, W.T.L., Passy P.F. (2018). Patterns of land change and their potential impacts on land surface temperature change in Yangon, Myanmar. Science of the Total Environment, 643, 738-750

Weng, Q. and Yang, S., (2006). Urban air pollution patterns, land use, and thermal landscape: an examination of the linkage using GIS. Environmental Monitosing and Assessment 117 (1), 463-489.

Wulder, M.A., White, J.C., Loveland, T.R., Woodcock, C.E., Belward, A.S., Cohen, W.B., Fosnight, E.A., Shaw, J., Masek, J.G. and Roy, D.P (2016). The global Landsat archive: Status, consolidation, and direction. Remote Sensing of Environment, 185, 271-283.

Yirsaw, E., Wu, W., Shi, X., Temesgen, H., \& Bekele, B. (2017). Land use/land cover change modeling and the prediction of subsequent changes in ecosystem service values in a coastal area of China, the Su-Xi-Chang Region. Sustainability, 9 (7), 1204.

Yue, W., Xu, J., Tan, W. and Xu, L. (2007). The relationship between land surface temperature and NDVI with remote sensing: application to Shanghai Landsat 7 ETM+ data. International Journal of Remote Sensing, 28 (15), 3205-3226.

Zha, Y., Gao, J. and Ni, S. (2005). Use of normalized difference built-up index in automatically mapping urban areas from TM imagery. International Journal of Remote Sen

Zhang, Y., Odeh, I. O., \& Han, C. (2009). Bi-temporal characterization of land surface temperature in relation to impervious surface area, NDVI and NDBI, using a sub-pixel image analysis. International Journal of Applied Earth Observation and Geoinformation, 11(4), 256-264 